\title{
A Practical Guide to Treatment of Hair Loss Beyond Standard Therapy
}

\author{
Kelley C. Ramsauer, MD
}

\section{PRACTICE POINTS}

- Keratin hair-building fibers can help thinning hair appear thick and full.

- Wigs are useful in masking moderate to severe hair loss.

- False eyelashes, eyebrow wigs, temporary eyebrow tattoos, microblading, and other semipermanent makeup can disguise the loss of eyelashes and eyebrows.

W hen I was a medical student rotating in dermatology, a patient with extensive alopecia looked at my long thick hair and said tearfully, "I just wish I could have hair like yours."

I smiled, removed my wig, and replied,"You can have hair like mine."

\section{Determination and Perseverance}

I was 2 years old when I was given a diagnosis of alopecia areata. Bald spots on my scalp would come and go for years but were not overly burdensome until I turned 12. At that point, my hair loss escalated despite frequent intralesional injections of triamcinolone; every 2 steps forward were followed by 3 steps backward.

As a freshman in high school, I finally took control of my condition and emotions, shaved my head, and purchased a wig-actions that confronted my hair loss and awoke a determination and perseverance that I did not think I would ever gain while living with this condition. As McGettigan ${ }^{1}$ wrote in the Journal of the American Academy of Dermatology in 2004, "Being diagnosed with [alopecia areata] does not mean one cannot have a full and meaningful life. By choosing to confront the condition and turn its negative aspects into positive actions, one can succeed in life." ${ }^{1}$

\section{As a Provider, Another Perspective}

Now, as a dermatology resident, I have the distinct perspective of being patient and provider. Patients often want to know, "Why is this happening?", "Is my hair going to grow back?", and "What treatments are available?"

They want to feel supported, understood, and heard.

As health care providers, we must understand that hair loss can result in overwhelming fear, hopelessness, and loss of self-esteem. Although we can give good news and offer helpful treatment options to some patients, there are those for whom medical treatment fails, and we can offer no more than a supportive hand and warm smile.

But can we do even more than that? The answer is:"Yes."

\section{Management Options}

I recommend that all patients with hair loss should receive a copy of the aforementioned McGettigan ${ }^{1}$ article, "Ahead With No Hair," which is geared toward patients with alopecia areata but offers inspiring words to any patient struggling to cope with hair loss. Dermatologists also can offer management options for patients with hair loss, including camouflage, wigs, and cosmetic replacement of eyelashes and eyebrows. Of note, several companies offer wigs and brow replacement options for men and children.

Camouflage-We can offer creative and readily available camouflage options for patients with hair loss. For small bald spots and thinning hair on the scalp, keratin hair-building fibers can be extremely useful. This overthe-counter product comes in a variety of natural hair colors, conceals the underlying skin, and adds fullness to hair. The keratin fibers have an innate static charge that allows them to adhere to the hair shaft. Daily application typically is necessary; duration can be maximized if hair spray or other brand-specific bonding spray is used following application of the fibers. A simple online search using the term keratin hair building fibers will reveal many

From the Department of Dermatology, Geisinger Medical Center, Danville, Pennsylvania.

The author reports no conflict of interest.

Correspondence: Kelley C. Ramsauer, MD, 16 Woodbine Ln, Danville, PA 17821 (kramsauer@tricitiesderm.com).

doi:10.12788/cutis.0236 
online and in-store options with 4- or 5-star reviews. Most negative reviews pertain to sweating or moisture that causes clumping, but overall this is an easy and affordable option for mild hair loss.

Wigs-For patients hoping to mask moderate or severe hair loss, I recommend wigs, which can be made from synthetic fibers or human hair. In order to effectively guide patients, it is helpful for providers to have some knowledge about the 2 types of wigs. Synthetic wigs are of variable quality, ranging from costume-grade to top-quality products that look and feel like human hair. They are more affordable and often are easier to maintain than humanhair wigs, and hairstyles hold up better after washing.

TABLE 1. Overview of Wig Types

\begin{tabular}{|c|c|c|c|c|}
\hline Hair Type & Cap Construction & Cost, $\$^{a}$ & Advantages & Limitations \\
\hline \multirow[t]{4}{*}{ Synthetic ${ }^{b}$} & Basic or wefted & $20-100$ & $\begin{array}{l}\text { Affordable; open wefting } \\
\text { allows for better air ventilation; } \\
\text { hair is preteased at the root to } \\
\text { help mask the cap beneath, } \\
\text { adding volume }\end{array}$ & $\begin{array}{l}\text { Not as natural-appearing as hand-tied } \\
\text { monofilament or lace-front wigs; possible } \\
\text { styling limitations based on properties of the } \\
\text { synthetic hair }\end{array}$ \\
\hline & Lace front & $50-500$ & $\begin{array}{l}\text { Hair is hand-tied to a strip of } \\
\text { lace along the frontal hairline; } \\
\text { natural-looking frontal hairline; } \\
\text { allows for styling hair away from } \\
\text { the face }\end{array}$ & $\begin{array}{l}\text { Made with a delicate lace material that } \\
\text { should be handled with care; possible styling } \\
\text { limitations based on the properties of the } \\
\text { synthetic hair }\end{array}$ \\
\hline & Monofilament & $60-300$ & $\begin{array}{l}\text { Natural look with parting } \\
\text { versatility; mesh monofilament } \\
\text { material gives the illusion of hair } \\
\text { growth from the scalp }\end{array}$ & $\begin{array}{l}\text { Possible styling limitations based on the } \\
\text { properties of the synthetic hair }\end{array}$ \\
\hline & $\begin{array}{l}\text { Hand-tied } \\
\text { monofilament }\end{array}$ & $100-500$ & $\begin{array}{l}100 \% \text { hand-tied monofilament } \\
\text { caps allow each hair to move } \\
\text { freely for the most natural look; } \\
\text { the soft and comfortable cap is } \\
\text { ideal for sensitive scalps }\end{array}$ & $\begin{array}{l}\text { Higher cost than other synthetic options; } \\
\text { possible styling limitations based on the } \\
\text { properties of the synthetic hair }\end{array}$ \\
\hline \multirow[t]{3}{*}{ Human $^{c}$} & Lace front & & $\begin{array}{l}\text { Similar advantages as a } \\
\text { synthetic lace-front wig except } \\
\text { that human hair might look or } \\
\text { feel more natural }\end{array}$ & $\begin{array}{l}\text { Made with a delicate lace material that } \\
\text { should be handled with care; limitations } \\
\text { on parting and styling compared to full- } \\
\text { lace caps }\end{array}$ \\
\hline & Full lac & $200-5000$ & $\begin{array}{l}\text { Most realistic wig option, } \\
\text { combining full-lace cap with } \\
\text { human hair; } 100 \% \text { hand-tied } \\
\text { cap allows each hair to move } \\
\text { freely for the most natural look; } \\
\text { can be custom made to match } \\
\text { the patient's ethnicity and } \\
\text { natural hair texture, color, } \\
\text { and density }\end{array}$ & $\begin{array}{l}\text { May be very expensive; requires glue or } \\
\text { wig tape to be kept in place; made with a } \\
\text { delicate lace material that should be } \\
\text { handled with care }\end{array}$ \\
\hline & $\begin{array}{l}\text { Other cap } \\
\text { constructions } \\
\text { (constantly } \\
\text { evolving } \\
\text { technology) }\end{array}$ & Variable & $\begin{array}{l}\text { Silk-top caps hide hand-tied } \\
\text { knots; alopecia caps are made } \\
\text { using polyurethane or silicone } \\
\text { to imitate thin skin, ensuring } \\
\text { better adherence of the wig to } \\
\text { the scalp }\end{array}$ & $\begin{array}{l}\text { May increase the cost of the wig slightly; } \\
\text { decreased ventilation, meaning the scalp } \\
\text { may become hot or sweaty }\end{array}$ \\
\hline
\end{tabular}

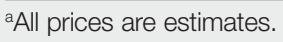

bynthetic wigs generally are more affordable and often easier to maintain than human-hair wigs and are better at holding their style after washing.

'Wigs made from human hair look and feel real but must be restyled after washing. 
Many synthetic wigs cannot withstand heat from a hot iron and have a slightly shorter lifespan (6-12 months) than human-hair wigs (1-2 years).

Human hair wigs are made of real human hair, so they look and feel natural. These wigs can be made from European, African, Indian, Malaysian, Chinese, or other ethnic hair. Patients can choose the texture of the hair, including silky (smooth), kinky (mimicking natural blowdried Black hair), and yaki (mimicking relaxed Black hair), as well as the curl pattern (straight, wavy, or curly), length, color, density, and cap construction.

The cap of a wig is what the hair is tied to. The construction of wig caps varies to allow for realistic hair lines as well as security for active use or up-dos. Among the many cap-construction options, the most realisticappearing are hand-tied monofilament, lace-front, and full-lace wigs, all of which may require tape or glue to keep them in place. Some wig companies offer nonslip so-called "alopecia caps" for patients with no scalp hair. Patients who find their wig irritating to the scalp should consider wearing a nylon wig cap or liner.
Wigs can be purchased in store or online and can be pre-made or custom-built to be tailored to the patient's specific desires and expectations. The cost depends on the type and quality of hair, cap construction, and length; prices can range from less than $\$ 100$ to more than $\$ 5000$.

When choosing a wig, which option-synthetic or human hair-is better for a given patient? Synthetic wigs are rather inexpensive and easy to care for, making them great for new users and those who want to try different styles and colors. Human-hair wigs can be custom-made to match the patient's natural hair; however, they require extra care to maintain their longevity. Both types of wigs have pros and cons depending on the patient's budget, time required for maintenance and styling, and needs (Table 1). I encourage patients to have fun with all wig options: Now is the time, I tell them, to try out the cute or daring hair style they have always wanted. The great thing is that if the patient does not like their wig, they can readily change it.

Good-quality wigs are expensive but sometimes are necessary to regain self-confidence and improve one's

TABLE 2. Eyelash Replacement Options

\begin{tabular}{|c|c|c|c|c|}
\hline Product type & Cost, $\$^{a}$ & Advantages & Limitations & Tips and Advice \\
\hline Strip lashes & $2-15$ & $\begin{array}{l}\text { Easily accessible and } \\
\text { affordable; relatively easy to } \\
\text { apply using eyelash glue; } \\
\text { may stay in place for } 1 \text { to } \\
\text { several days if kept dry; } \\
\text { a single set can last } 1 \text { to } \\
\text { several weeks; natural lashes } \\
\text { are not required }\end{array}$ & $\begin{array}{l}\text { Glue may stick to remaining } \\
\text { lashes and increase shedding } \\
\text { when strip lashes are } \\
\text { removed; the glue might } \\
\text { loosen or come off with } \\
\text { bathing, heavy sweating, } \\
\text { and water-related activities }\end{array}$ & $\begin{array}{l}\text { Procedure: Once glue is } \\
\text { applied to the lash strip, let } \\
\text { it sit for } 30-45 \text { sec to get } \\
\text { sticky, then carefully apply } \\
\text { the strip to the natural } \\
\text { lash line, starting with the } \\
\text { inner or outer edge; use } \\
\text { of eyeliner before or after } \\
\text { application might improve } \\
\text { the aesthetic outcome }\end{array}$ \\
\hline $\begin{array}{l}\text { Individual } \\
\text { false lashes }\end{array}$ & & $\begin{array}{l}\text { Easily accessible and } \\
\text { affordable; applied at home } \\
\text { using eyelash glue; may stay } \\
\text { in place for } 1 \text { to several days } \\
\text { if kept dry; natural lashes are } \\
\text { not required }\end{array}$ & $\begin{array}{l}\text { Lashes are individually glued } \\
\text { to the eyelid margin, which } \\
\text { takes longer than applying } \\
\text { strip lashes and requires a } \\
\text { steady hand; the glue may } \\
\text { loosen or come off with } \\
\text { bathing, heavy sweating, } \\
\text { and water-related activities }\end{array}$ & $\begin{array}{l}\text { Use of eyeliner before } \\
\text { or after application may } \\
\text { improve the aesthetic } \\
\text { outcome }\end{array}$ \\
\hline $\begin{array}{l}\text { Magnetic } \\
\text { strip lashes }\end{array}$ & $5-30$ & $\begin{array}{l}\text { Easily accessible and } \\
\text { affordable; easy to use; glue } \\
\text { is not required }\end{array}$ & $\begin{array}{l}\text { Must have natural eyelashes } \\
\text { for the magnetic strips to } \\
\text { adhere }\end{array}$ & $\begin{array}{l}\text { Procedure: apply a } \\
\text { magnetized strip of lashes } \\
\text { on top of the natural lashes } \\
\text { and a second strip below } \\
\text { the natural lashes }\end{array}$ \\
\hline $\begin{array}{l}\text { Lash } \\
\text { extensions }\end{array}$ & $\begin{array}{l}\text { 100-400 (initial } \\
\text { application), } \\
\text { 50-150 (every } \\
\text { 2-4 wk for } \\
\text { maintenance) }\end{array}$ & $\begin{array}{l}\text { Long lasting }(6-8 \text { wk); more } \\
\text { water-resistant than strip } \\
\text { and individual lashes }\end{array}$ & $\begin{array}{l}\text { Must be applied by a } \\
\text { technician; patient must have } \\
\text { natural lashes; may increase } \\
\text { shedding of natural lashes; } \\
\text { expensive }\end{array}$ & \\
\hline
\end{tabular}

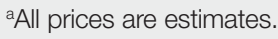


quality of life. Advise patients to call their health insurance company to find out if a cranial or scalp prosthesis is covered by their policy. Coverage might require a written prescription for a cranial prosthesis, listing the diagnosis, diagnosis code, and letter of medical necessity. Patients can then purchase the wig online or through a certified distributor depending on their insurance requirements and obtain reimbursement (partial or full coverage). If a wig is not covered by insurance, a cranial prosthesis might be a flexible spending account-eligible expense. For guidance on the reimbursability of wigs, visit the National Alopecia Areata Foundation (NAAF) website (www.naaf.org/AccessHealthcare).

Eyelashes and Eyebrows-Cosmetic replacement of eyelashes (Table 2) and eyebrows (Table 3) is another treatment option that physicians can offer to hair-loss patients. For patients who desire false eyelashes, strip lashes that are glued to the eyelid margin are easiest to apply (but with caution-do not get glue in the eyes!). There are magnetic lashes, but these require natural lashes on which to adhere them. Eyebrows can be handdrawn using brow pencils or powders with or without a stencil to maintain symmetry. There are even brow wigs and temporary brow tattoos that can last 1 to several days. Semi-permanent tattooing, including microblading, is an option that has amazing results but can be painful and expensive, often requiring touch-ups every 6 to 18 months.

\section{Resources Abound}

Experiencing and treating hair loss can be overwhelming, but there are countless resources available for patients. The NAAF has utility beyond the concerns of alopecia areata patients; there also is useful information on YouTube and social media, and support groups exist for hair-loss patients. I recommend starting with the NAAF website, which offers many helpful resources and support groups for patients and their families, including tips on applying for insurance reimbursement and drafting an appeal letter. Lastly, several nonprofit organizations serve the hair-replacement needs of children and adults with hair loss (Table 4).

\section{Final Thoughts}

My experience as a patient with alopecia has been long and initially was challenging; however, I found the silver lining after choosing to confront my literal and figurative "losses" and move forward-to grow, so to

TABLE 3. Eyebrow Replacement Options

\begin{tabular}{|c|c|c|c|c|}
\hline Product Type & Cost, $\$^{a}$ & Advantages & Limitations & Tips and Advice \\
\hline $\begin{array}{l}\text { Eyebrow } \\
\text { pencil or brow } \\
\text { powder (hand } \\
\text { drawn) }\end{array}$ & $<20$ & Inexp & $\begin{array}{l}\text { Must be applied daily; } \\
\text { might smudge or smear } \\
\text { throughout the day; } \\
\text { takes practice to get } \\
\text { desired result }\end{array}$ & $\begin{array}{l}\text { Brow stencils can be used to aid } \\
\text { in obtaining the desired shape } \\
\text { and symmetry }\end{array}$ \\
\hline $\begin{array}{l}\text { Temporary } \\
\text { eyebrow } \\
\text { tattoos }\end{array}$ & $\begin{array}{l}10- \\
\text { (pac }\end{array}$ & $\begin{array}{l}\text { Inexpensive; defined, hair-like } \\
\text { strokes that are detailed and } \\
\text { appear realistic; can last } \\
1 \text { to several days without } \\
\text { smudging or smearing; easy } \\
\text { to use }\end{array}$ & $\begin{array}{l}\text { Not a good option } \\
\text { for people with full } \\
\text { eyebrows, best for } \\
\text { patchy or lost eyebrows }\end{array}$ & $\begin{array}{l}\text { Use scissors to cut brow tattoos } \\
\text { from packaging; brows can } \\
\text { be thinned or further shaped } \\
\text { with scissors if desired; remove } \\
\text { plastic covering, place on desired } \\
\text { location, dampen, and press and } \\
\text { hold for } 10-15 \mathrm{sec}\end{array}$ \\
\hline Eyebrow wigs & $50-150$ & $\begin{array}{l}\text { Made from real hair; applied } \\
\text { using specialized glue; may } \\
\text { stay in place for } 1 \text { to several } \\
\text { days; typically last } 2-4 \text { mo }\end{array}$ & $\begin{array}{l}\text { Not a good option } \\
\text { for people with full } \\
\text { eyebrows, best for } \\
\text { patchy or lost eyebrows; } \\
\text { expensive }\end{array}$ & $\begin{array}{l}\text { Nightly removal of eyebrow } \\
\text { wigs may increase longevity of } \\
\text { the product }\end{array}$ \\
\hline $\begin{array}{l}\text { Microblading } \\
\text { and semi- } \\
\text { permanent } \\
\text { tattooing }\end{array}$ & $\begin{array}{l}\text { 300-2000 } \\
\text { (initial } \\
\text { treatment), } \\
100-300 \\
\text { (touch-up } \\
\text { session every } \\
6-18 \mathrm{mo} \text { ) }\end{array}$ & $\begin{array}{l}\text { Realistic-appearing, } \\
\text { semi-permanent makeup; } \\
\text { longer lasting }\end{array}$ & $\begin{array}{l}\text { Can be painful; takes } \\
\text { approximately } 1 \text { wk } \\
\text { to fully heal after } \\
\text { procedure; fades } \\
\text { with time; ongoing } \\
\text { maintenance (touch- } \\
\text { ups) required; expensive }\end{array}$ & $\begin{array}{l}\text { Microblading and tattooing } \\
\text { introduce semi-permanent } \\
\text { pigment into the skin; } \\
\text { microblading uses a small blade } \\
\text { to make hair-stroke cuts, followed } \\
\text { by application of ink; tattooing } \\
\text { uses a tattoo gun to insert ink } \\
\text { under the skin }\end{array}$ \\
\hline
\end{tabular}

${ }^{\mathrm{a} A l l}$ prices are estimates. 
TABLE 4. Nonprofit Wig Organizations ${ }^{a}$

\begin{tabular}{|c|c|}
\hline Organization (website ${ }^{b}$ ) & Population served \\
\hline $\begin{array}{l}\text { AngelHair Inc. } \\
\text { (https://angelhairforcancer.org/application) }\end{array}$ & $\begin{array}{l}\text { Provides customized wigs at no cost to women with hair loss due } \\
\text { to cancer drugs and treatments }\end{array}$ \\
\hline $\begin{array}{l}\text { Children With Hair Loss } \\
\text { (https://childrenwithhairloss.us/apply-for-hair/hair-application) }\end{array}$ & $\begin{array}{l}\text { Provides annual human-hair replacements along with a complete } \\
\text { care kit at no cost to children and young adults ( } \leq 21 \text { y) facing } \\
\text { medically related hair loss }\end{array}$ \\
\hline $\begin{array}{l}\text { EBeauty Community Inc. } \\
\text { (www.ebeauty.com/wig-exchange-program/) }\end{array}$ & $\begin{array}{l}\text { A wig exchange program in which anyone can donate a wig they } \\
\text { no longer need; EBeauty Community cleans and refurbishes the } \\
\text { wig and provides it at no cost to women undergoing chemotherapy }\end{array}$ \\
\hline $\begin{array}{l}\text { Hair We Share } \\
\text { (https://hairweshare.org/wig-application) }\end{array}$ & $\begin{array}{l}\text { Provides wigs free of charge to children aged }<18 \text { y who have } \\
\text { a medical condition that causes hair loss, as well as to men and } \\
\text { women aged }>18 \text { y based on financial need }\end{array}$ \\
\hline $\begin{array}{l}\text { Locks of Love } \\
\text { (https://locksoflove.org/forms) }\end{array}$ & $\begin{array}{l}\text { Provides custom hair replacements at no cost to financially } \\
\text { disadvantaged children and young adults ( } \leq 21 \text { y) facing medically } \\
\text { related hair loss }\end{array}$ \\
\hline $\begin{array}{l}\text { Wigs For Kids } \\
\text { (www.wigsforkids.org/apply-for-a-wig/how-to-apply) }\end{array}$ & $\begin{array}{l}\text { Provides custom-made human-hair wigs for children aged } \leq 18 \text { y } \\
\text { who have lost their hair due to medical causes; wigs are made to } \\
\text { withstand kids playing and engaging in normal activities without } \\
\text { worrying about keeping them in place }\end{array}$ \\
\hline
\end{tabular}

speak. With the use of custom-made human-hair wigs, false strip eyelashes, and a mix of eyebrow replacement options, I have been able to regain my confidence and self-esteem. Now, my goal as a physician-a goal that I hope you will share-is to be knowledgeable about hair-replacement options and provide information and resources to patients to help them feel empowered, brave, and beautiful.

\section{REFERENCE}

1. McGettigan ML. Ahead with no hair. J Am Acad Dermatol. 2004;51 (1 suppl):18-19. 